\title{
Biological influences on morphology and bed composition of an intertidal flat
}

\author{
A.J. Paarlberg ${ }^{\text {a,* }}$, M.A.F. Knaapen ${ }^{\text {a }}$, M.B. de Vries ${ }^{\text {a,b }}$, \\ S.J.M.H. Hulscher ${ }^{\mathrm{a}}$, Z.B. Wang ${ }^{\text {b,c }}$ \\ ${ }^{a}$ Water Engineering \& Management, University of Twente, P.O. Box 217, 7500 AE Enschede, The Netherlands \\ ${ }^{\mathrm{b}}$ WL $\mid$ Delft Hydraulics, Rotterdamseweg 185, P.O. Box 177, Delft, The Netherlands \\ ${ }^{\mathrm{c}}$ Faculty of Civil Engineering and Geosciences, Delft University of Technology, Stevinweg 1, P.O. Box 5048, \\ 2600 GA, Delft, The Netherlands
}

Received 8 March 2004; accepted 8 April 2005

Available online 27 June 2005

\begin{abstract}
Biological activity is known to influence sediment strength at bed-water interfaces. However, its precise effect on geomorphology and on bed composition is not known. This paper proposes a parameterization of sediment destabilizing and stabilizing organisms on three parameters that describe the erosion and mixing processes of the sediment bed, namely the critical bed shear stress, the erosion coefficient and the bioturbation coefficient. This parameterization is included in a $3 \mathrm{D}$ sand-mud morphodynamic model to form the sand-mud-bio model. The performance of the sand-mud-bio model is demonstrated by testing it on the Paulinapolder intertidal flat in the Western Scheldt estuary of The Netherlands. Model results show that biological influences on sediment strength result in significant morphological change and bed composition variations. Destabilizing organisms always cause a significant decrease in mud content in the bed and an increase of erosion. On the other hand, stabilizing organisms can, but do not necessarily, cause an increase of mud content and additional sedimentation.
\end{abstract}

(c) 2005 Elsevier Ltd. All rights reserved.

Keywords: biological activity; erosion; sedimentation; modeling; sand/mud; geomorphology; Paulinapolder; Western Scheldt

\section{Introduction}

Biogeomorphology deals with the study of the interaction between organisms and the bed they are living on or living in. For water management purposes, it is important to predict the geomorphological effects of human interventions or natural changes of an estuarine system. A better understanding of the geomorphological behaviour of estuarine systems requires better knowledge about the physical processes involved, the performance of geomorphological modelling techniques, the

\footnotetext{
* Corresponding author.

E-mail address: a.j.paarlberg@utwente.nl (A.J. Paarlberg).
}

interaction between biology and geomorphology, and the biological influences on bed composition. Widdows and Brinsley (2002) state that, at present, "...lack of knowledge of the precise nature of biological-sediment interaction coupled with a poor understanding of how to parameterize biological effects so that they can be incorporated into numerical sediment transport and geomorphological models is a major impediment to progress".

Experiments on different mudflats in the Western Scheldt estuary (De Brouwer et al., 2000; Widdows et al., 2000a; Widdows and Brinsley, 2002), the Humber estuary (Widdows et al., 1998, 2000b; De Deckere et al., 2001; Widdows and Brinsley, 2002), the Danish Wadden Sea (Austen et al., 1999), and the laboratory 
(Quaresma et al., 2004) have shown that sediment strength parameters are influenced by several orders of magnitude when biological activity is high. Using an onshore-offshore 1D model of cohesive sediment erosion and deposition, Wood and Widdows (2002) have shown that biotic influences on sediment transport within the intertidal zone are significant.

This paper addresses the question of whether biological influences on three critical sediment strength parameters cause significant changes in geomorphology and vertical bed composition (namely sand/mud distribution). To date, adequate parameterization of biological influences for the purpose of sediment transport modelling is lacking. This paper introduces parameterization of such biological influences. Stabilization and destabilization effects of biota on erosion, and bioturbation have been parameterized on the basis of experimental data published by Widdows et al. (1998, 2000a,b) and Widdows and Brinsley (2002). This parameterization is incorporated in a process-based sand-mud model (Van Ledden and Wang, 2001; Van Ledden, 2002, 2003; Van Ledden et al., 2004b) to form the sand-mud-bio model.

The performance of the sand-mud-bio model is demonstrated by testing it on the Paulinapolder, a small intertidal flat located on the southern shore of the Western Scheldt estuary, approximately $6 \mathrm{~km}$ northeast of Terneuzen $\left(51^{\circ} 25^{\prime} \mathrm{N}, 3^{\circ} 40^{\prime} \mathrm{E}\right)$ of the Western Scheldt estuary, The Netherlands (Fig. 1). A reference situation free of biological activity is set-up, which in general agrees with hydrodynamical data and agrees with the expected morphological behaviour of the flat. Then, three test cases are analyzed to study the biological influences on morphological change and bed composition.

\section{Biostabilization and biodestabilization}

Earlier researchers such as Jumars and Nowell (1984) recognized the effect of benthos on sediment transport. It has become clear that benthic species can stabilize the sediment by physically covering it (e.g. mussel beds) or by binding it by roots. Biostabilization can also result from extracellular polymeric substances (EPS) excreted by diatoms that cohere sediment (Austen et al., 1999; De Brouwer et al., 2000; Decho, 2000; Paterson et al., 2000; Riethmüller et al., 2000). During a bloom period in spring, large amounts of diatoms are known to form diatom mats, which are sometimes visible as a brownish jelly-like layer on the sediment (De Brouwer et al., 2000; Widdows et al., 2000b).

Some species that live on or below the surface (for instance Mudsnail, Cockle, Lugworm) destabilize the sediment due to deposit feeding activity or increased mixing (bioturbation, see e.g. Boudreau, 1997). This causes increased porosity and changing sediment composition (De Brouwer et al., 2000; De Deckere et al., 2001; Reise, 2002), which may result in less stable sediment (Widdows et al., 2000a,b).

Biostabilization and biodestabilization influence two sediment transport parameters in particular: the critical

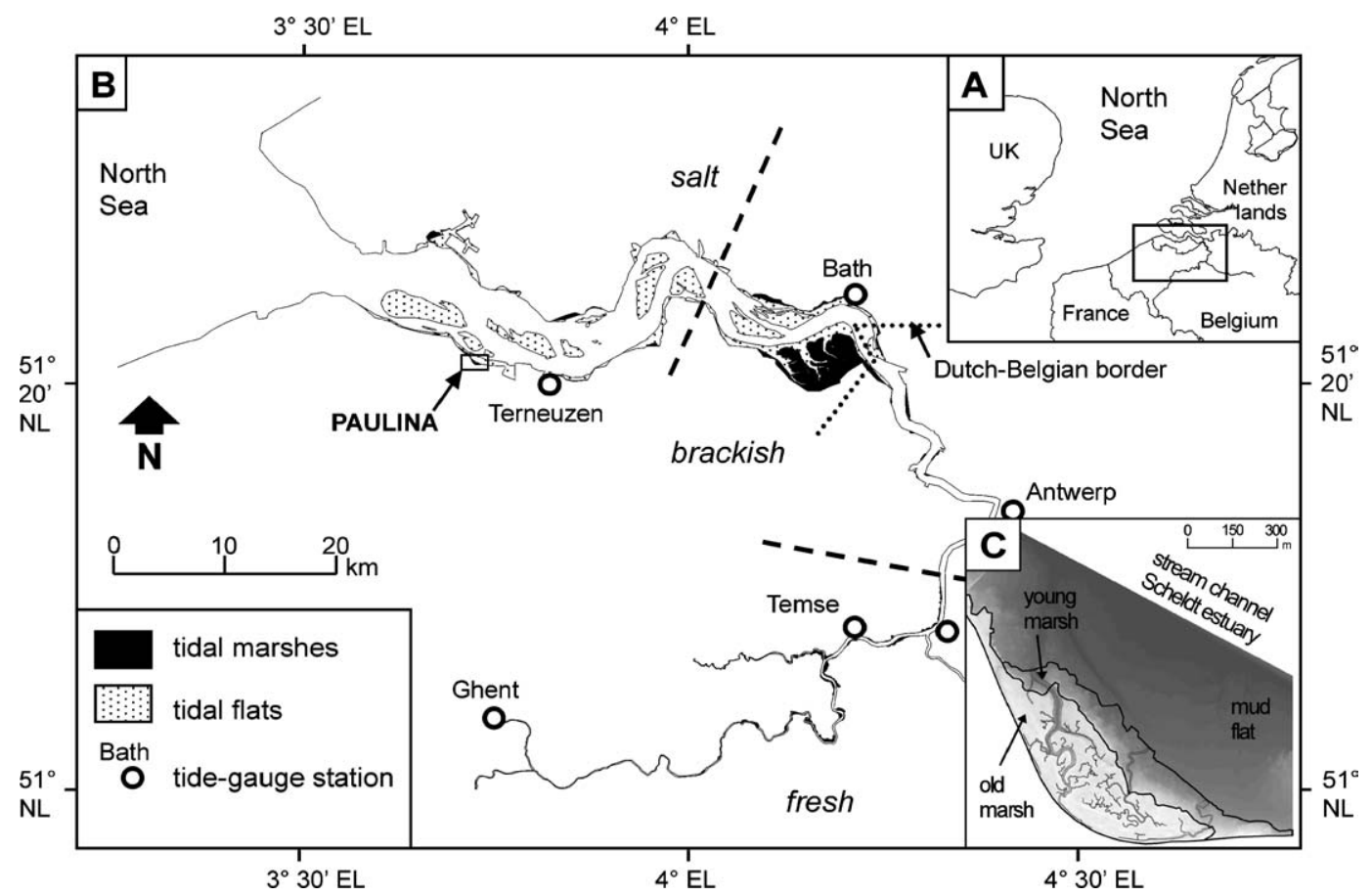

Fig. 1. Location of the Paulinapolder (c) in the Western Scheldt estuary (b) of The Netherlands (a). Figure modified from Temmerman et al. (2003). 
bed shear stress and the erosion coefficient. Changes in these two parameters, and a changing rate of bioturbation, can result in a different bed level and bed composition. We analyze the biological influence of diatoms and the bivalve Macoma balthica, which is commonly found on mudflats. These biota are representatives of organisms with biostabilizing and biodestabilizing effects, respectively (Widdows et al., 1998, 2000a,b; De Brouwer et al., 2000; Staats et al., 2001; Widdows and Brinsley, 2002).

Knaapen et al. (2003) have included the influence of destabilizing and stabilizing organisms on the critical bed shear stress in a 1DV sand-mud model. This model shows that sediment on the Molenplaat intertidal flat in the Western Scheldt estuary of The Netherlands is destabilized by organisms. The mud content shows a decrease of $10-20$ weight- $\%$ compared to the mud content calculated over one year without biological influence.

This paper focuses on biostabilization and biodestabilization, though the description of combined biological effects is complicated due to species interactions, very specific species-dependent behaviour and the combination of (de)stabilization effects within same species groups (Jumars and Nowell, 1984). Interactions between organisms, and the effects of sediment transport, bed level changes, and bed composition changes on biological activity are not taken into account. Also the processes bio(re)suspension and biodeposition (see e.g. Lee and Swartz, 1980) are not taken into account.

\section{Sand-mud-bio model}

This paper uses an available process-based sandmud model (Van Ledden and Wang, 2001; Van Ledden, 2002, 2003; Van Ledden et al., 2004b) which is based on the numerical modelling system Delft3D (D3D). D3D can be applied for hydrodynamic and morphodynamic simulations of coastal, river and estuarine areas. Application of the sand-mud model to the Friesche Zeegat (The Netherlands) resulted in realistic distributions of sand and mud when compared with in situ measurements (Van Ledden and Wang, 2001; Van Ledden, 2003).

\subsection{Sand-mud model description}

As an extension to $\mathrm{D} 3 \mathrm{D}$, the sand-mud model calculates the bed composition over time and in space. Erosion formulations for sand-mud mixtures are applied (Van Ledden et al., 2004b). The model has two sediment fractions: a non-cohesive sand fraction and a cohesive mud fraction $\left(d_{50} \leq 0.063 \mathrm{~mm}\right)$ (Van Ledden, 2002, 2003). Cohesive beds form a coherent mass because of electrochemical interactions between sediment particles. These interactions dominate the erosional behaviour, whereas the particle size and weight are of minor importance. Only clay particles $\left(d_{50} \leq 0.002 \mathrm{~mm}\right)$ within the mud fraction have cohesive properties.

In general, the ratio between the clay and the silt content in the sediment bed is fairly constant and therefore a critical mud content is applied to distinguish between the cohesive and the non-cohesive regime in the sand-mud model (Van Ledden et al., 2004a,b). If the mud content $\left(p_{\mathrm{m}}\right)$ in the sediment exchange layer which is the top $5 \mathrm{~cm}$ of the bed - is lower than the critical mud content $\left(p_{\mathrm{cr}}\right)$, erosion formulations for the non-cohesive regime are used.

Bed level changes depend on both sand and mud dynamics. The exchanges of sediment between the bed and the water column depend on the bed composition at the bed surface. The bed load sand transport rate is calculated after Van Rijn (1993, chapter 7). The net vertical fluxes of suspended sand $\left(F_{\mathrm{s}}\right)$ and mud $\left(F_{\mathrm{m}}\right)$ near the bed surface are as follows (Van Ledden and Wang, 2001; Van Ledden et al., 2004b):

Non-cohesive regime $\left(p_{\mathrm{m}} \leq p_{\mathrm{cr}}\right)$ :

$$
\begin{aligned}
F_{\mathrm{s}}= & w_{\mathrm{s}}\left(c_{\mathrm{a}}-c_{\mathrm{s}}\right) \\
F_{\mathrm{m}}= & p_{\mathrm{m}} M_{\mathrm{nc}}\left(\frac{\tau_{\mathrm{b}}}{\tau_{\mathrm{nc}}}-1\right) H\left(\frac{\tau_{\mathrm{b}}}{\tau_{\mathrm{nc}}}-1\right) \\
& -w_{\mathrm{m}} c_{\mathrm{m}}\left(1-\frac{\tau_{\mathrm{b}}}{\tau_{\mathrm{d}}}\right) H\left(1-\frac{\tau_{\mathrm{b}}}{\tau_{\mathrm{d}}}\right)
\end{aligned}
$$

Cohesive regime $\left(p_{\mathrm{m}}>p_{\mathrm{cr}}\right)$ :

$$
\begin{aligned}
F_{\mathrm{s}}=\left(1-p_{\mathrm{m}}\right) M_{\mathrm{c}}\left(\frac{\tau_{\mathrm{b}}}{\tau_{\mathrm{c}}}-1\right) H\left(\frac{\tau_{\mathrm{b}}}{\tau_{\mathrm{c}}}-1\right)-w_{\mathrm{s}} c_{\mathrm{s}} \\
F_{\mathrm{m}}=p_{\mathrm{m}} M_{\mathrm{c}}\left(\frac{\tau_{\mathrm{b}}}{\tau_{\mathrm{c}}}-1\right) H\left(\frac{\tau_{\mathrm{b}}}{\tau_{\mathrm{c}}}-1\right) \\
-w_{\mathrm{m}} c_{\mathrm{m}}\left(1-\frac{\tau_{\mathrm{b}}}{\tau_{\mathrm{d}}}\right) H\left(1-\frac{\tau_{\mathrm{b}}}{\tau_{\mathrm{d}}}\right)
\end{aligned}
$$

where $w_{\mathrm{s}}$ is the settling velocity for sand at $20{ }^{\circ} \mathrm{C}\left[\mathrm{m} \mathrm{s}^{-1}\right]$, $c_{\mathrm{a}}$ a reference sand volume concentration $[-], c_{\mathrm{s}}$ the sand volume concentration near the bed surface $[-], M_{\mathrm{c}}$ the erosion coefficient for the cohesive regime $\left[\mathrm{m} \mathrm{s}^{-1}\right], \tau_{\mathrm{b}}$ the bed shear stress $\left[\mathrm{N} \mathrm{m}^{-2}\right], \tau_{\mathrm{c}}$ the critical erosion shear stress for the cohesive regime $\left[\mathrm{N} \mathrm{m}^{-2}\right], M_{\mathrm{nc}}$ the erosion coefficient for the non-cohesive regime $\left[\mathrm{m} \mathrm{s}^{-1}\right], \tau_{\mathrm{nc}}$ the critical erosion shear stress for the non-cohesive regime $\left[\mathrm{N} \mathrm{m}^{-2}\right], w_{\mathrm{m}}$ the settling velocity for mud at $20{ }^{\circ} \mathrm{C}$ $\left[\mathrm{m} \mathrm{s}^{-1}\right], c_{\mathrm{m}}$ the mud concentration near the bed surface $[-]$, and $\tau_{\mathrm{d}}$ the critical shear stress for mud deposition $\left[\mathrm{N} \mathrm{m}^{-2}\right]$. The heavyside function $H$ is equal to 1 when 
the argument is positive and 0 when the argument is negative. For further details on the equations, the reader is referred to Van Ledden and Wang (2001) and Van Ledden (2002).

Spatial and temporal variations in bed composition are taken into account by applying the bed composition concept developed by Armanini (1995) in Lagrangian coordinates:

$\frac{\partial p_{\mathrm{m}}}{\partial t}+\frac{\partial z_{\mathrm{b}}}{\partial t} \frac{\partial p_{\mathrm{m}}}{\partial z_{\mathrm{c}}}-\frac{\partial}{\partial z_{\mathrm{c}}}\left(\theta_{\operatorname{mix}} \frac{\partial p_{\mathrm{m}}}{\partial z_{\mathrm{c}}}\right)=0$

where $z_{\mathrm{c}}$ is the distance below the bed surface $z_{\mathrm{b}}$, and $\theta_{\text {mix }}$ is a mixing coefficient. The origin of the coordinate $z_{\mathrm{c}}$ shifts upwards or downwards with bed level variations over time and $z_{\mathrm{c}}$ is positive in the downward direction (Van Ledden and Wang, 2001). The second term of Eq. (5) represents the effect of the moving origin of $z_{\mathrm{c}}$ due to the changing bed level. In the sediment bed, only the mud content in the bed is calculated explicitly. The changes in sand content in the bed follow from continuity. The mixing coefficient $\left(\theta_{\text {mix }}\right)$ consists of a physical mixing component due to small-scale bed level disturbances $\left(\theta_{\mathrm{p}}\right)$ and a local biological mixing component $\left(\theta_{\mathrm{b}}\right): \theta_{\text {mix }}=\theta_{\mathrm{p}}+\theta_{\mathrm{b}}$. The physical mixing coefficient is proportional to the shear velocity $\left(u_{*}\right)$ and the sand grain size $\left(d_{50}\right)$, and decreases exponentially with the distance from the bed surface, (after Armanini, 1995 and Van Ledden, 2002, 2003). The biological mixing coefficient is constant in the biological mixing zone (Van Ledden and Wang, 2001).

\subsection{Parameterization of the biological influence on sediment strength}

Biostabilization by diatoms is represented by a Chlorophyll $a$ content $\left[\mu \mathrm{g} \mathrm{g}^{-1}\right.$ ] (which is an indicator of microphytobenthos biomass (Staats et al., 2001)), and is modelled as an increase of the critical bed shear stress and a decrease of the erosion coefficient. Biodestabilizing organisms are represented by the abundance [indiv. $\mathrm{m}^{-2}$ ] of deposit feeders (after Austen et al., 1999), in this paper Macoma balthica, and can be modelled by a reduction of the critical bed shear stress and an increase of the erosion coefficient. Further, destabilizing organisms cause an increase in the bioturbation coefficient. This leads to the following hypotheses:

$$
\begin{aligned}
& \tau_{\mathrm{nc}}=\tau_{\mathrm{nc}}^{0} f_{\mathrm{s}}(C) f_{\mathrm{d}}(B) \\
& \tau_{\mathrm{c}}=\tau_{\mathrm{c}}^{0} f_{\mathrm{s}}(C) f_{\mathrm{d}}(B) \\
& M_{\mathrm{nc}}=M_{\mathrm{nc}}^{0} g_{\mathrm{s}}(C) g_{\mathrm{d}}(B)
\end{aligned}
$$

$$
M_{\mathrm{c}}=M_{\mathrm{c}}^{0} g_{\mathrm{s}}(C) g_{\mathrm{d}}(B)
$$

$\theta_{\mathrm{d}}=g_{\mathrm{d}}(B) \theta_{\mathrm{b}}$

where $\tau_{\mathrm{nc}}$ and $\tau_{\mathrm{c}}$ are the critical bed shear stress for the non-cohesive and cohesive regime, respectively, $M_{\mathrm{nc}}$ and $M_{\mathrm{c}}$ are the erosion coefficient for the non-cohesive and cohesive regime, respectively and $\theta_{\mathrm{d}}$ the bioturbation coefficient including biological activity. The superscript ' 0 ' represents values without influence of biological activity. $f_{\mathrm{s}}$ and $f_{\mathrm{d}}$ denote the stabilizing and destabilizing influences on the critical bed shear stress respectively, and $g_{\mathrm{s}}$ and $g_{\mathrm{d}}$ denote the stabilizing and destabilizing influences on the erosion coefficient respectively. $C$ is the Chlorophyll $a$ content in the sediment and $B$ is the dimensionless Macoma abundance (actual Macoma density $\left(N_{\mathrm{B}}\right)$ divided by a reference density $\left(B_{\text {ref }}\right)$ of 1 indiv. $\left.\mathrm{m}^{-2}: B=N_{\mathrm{B}} / B_{\text {ref }}\right)$. The latter division is necessary to get a non-dimensional parameter to avoid dimensional problems as explained by Flemming and Delafontaine (2000). The bioturbation coefficient is assumed to depend solely on the abundance of destabilizing organisms.

\subsection{Biological influences on the critical bed shear stress}

Knaapen et al. (2003) parameterized the effect of stabilizing organisms on the critical bed shear stress $\left(f_{\mathrm{s}}\right)$ using data reported by Widdows et al. (2000a). The relationship gives a coefficient of determination of $R^{2}=0.60$ in field measurements. This coefficient is not very high, and it is based on a relatively small data set.

$f_{s}(C)=0.07 C+1$

Knaapen et al. (2003) used data of Widdows et al. (2000b) to parameterize the destabilizing influence on the critical bed shear stress $\left(f_{\mathrm{d}}\right)$. The data had to be corrected, because diatoms were present during measurements.

$f_{\mathrm{d}}(B)=0.0016 \ln (B)^{2}-0.085 \ln (B)+1$

The relationships presented here show strong similarities with the relationship found by Austen et al. (1999), which are deduced from experimental data of the Lister Dyb tidal area in the Danish Wadden Sea. Fig. 2a shows the biological influences on the critical bed shear stress. Macoma densities higher than about 2000 indiv. $\mathrm{m}^{-2}$ do not result in an additional effect on the critical bed shear stress if the diatom content remains constant. 

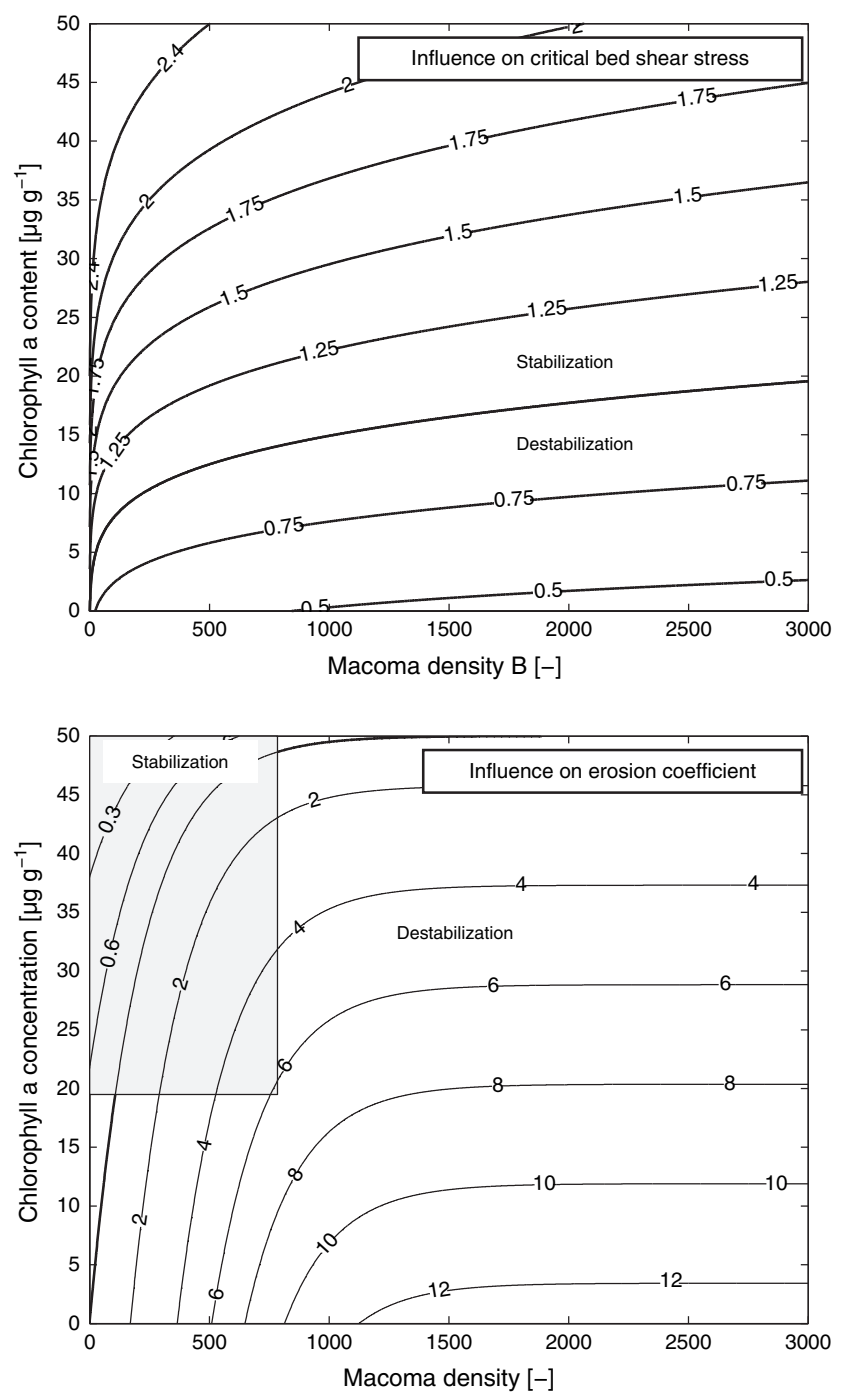

Fig. 2. Biological influences on critical bed shear stress (a) and erosion coefficient (b). The thick line is the transition between stabilization and destabilization and represents the situation without biological influence. The shaded area in (b) indicates the range in which data are available.

\subsection{Biological influences on erosion coefficient}

To determine the influence of diatoms on the erosion coefficient, the analysis made by Widdows and Brinsley (2002) is used, which is based on data gathered from experiments in Nova Scotia, Canada (original data from Sutherland et al., 1998) (Fig. 3). These data show that the erosion coefficient is about $1 \times 10^{-6} \mathrm{~m} \mathrm{~s}^{-1}$ in the absence of diatoms in the bed. This value is used to scale the relationship, such that a correction factor of 1 is found when there are no diatoms present. Extrapolation with linear regression results in:

$g_{s}(C)=-0.018 C+1$

The destabilizing influence on the erosion coefficient $(M)$ is deduced from data presented by Widdows et al.

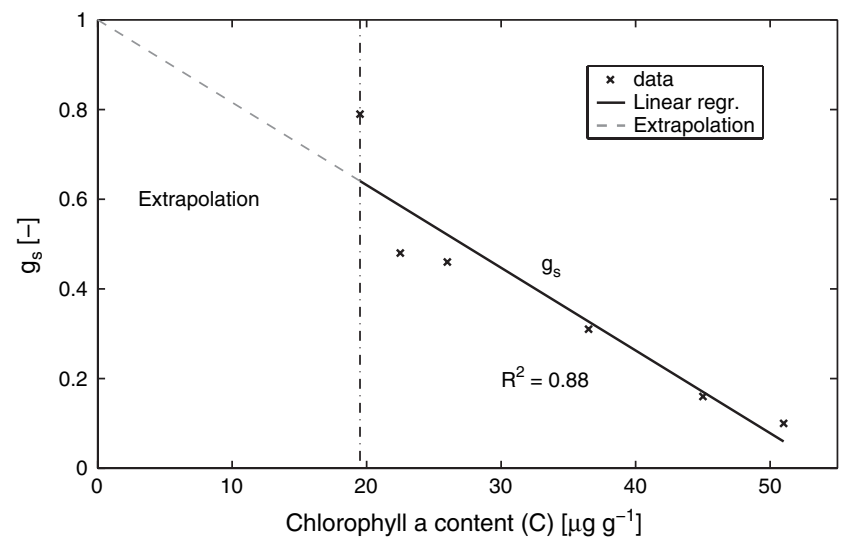

Fig. 3. Stabilizing biological influence on the erosion coefficient.

(2000a). The data are interpreted in light of assumed relations (6) and (7), and statistical relationships (11)-(13). It was necessary to correct for the fact that both the critical bed shear stress and the erosion coefficient determine the erosion flux (Eqs. (2)-(4)). An S-shaped curve is assumed which means that the biological influence increases, but only up to a maximum value and remains constant thereafter (Fig. 4). The maximum erosion coefficient $(\gamma)$ is $6 \times 10^{-7} \mathrm{~m} \mathrm{~s}^{-1}$ (derived from data presented by Widdows and Brinsley, 2002). The following relationship is found:

$g_{\mathrm{d}}(B)=\frac{b_{2} \gamma}{\left(b_{2}+\gamma\left[b_{1}\right]^{B}\right) I}$

where $b_{1}=0.995$ and $b_{2}=5.08 \times 10^{-8} \mathrm{~m} \mathrm{~s}^{-1}$ (both regression coefficients), and $I$ the erosion coefficient without biological activity (to scale the relationship) is $4.68 \times 10^{-8} \mathrm{~m} \mathrm{~s}^{-1}$ (derived from data presented by Widdows et al., 2000a). Fig. 2b shows the biological influences on the erosion coefficient. It should be noted that few data are used to derive the relationships presented in Eqs. (13) and (14) (see also Fig. 2). Eqs. (11)-(14) are implemented in the sand-mud model as correction factors on the critical bed shear stress, the

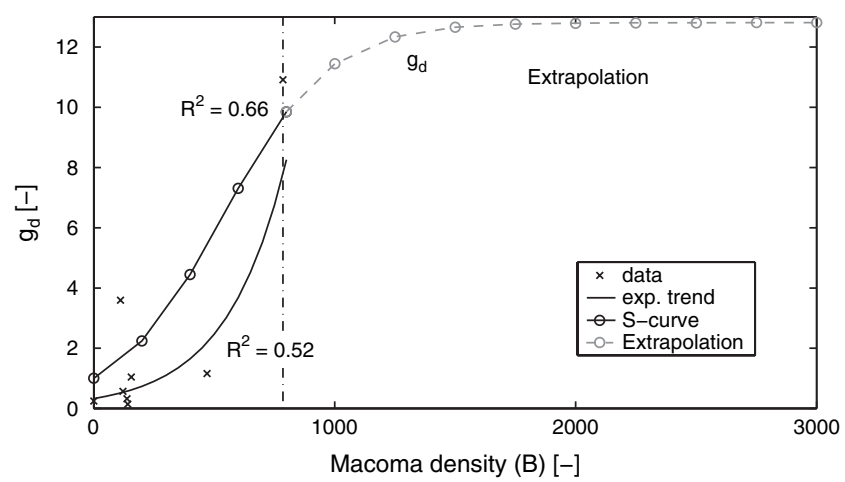

Fig. 4. Destabilizing biological influence on the erosion coefficient. 
erosion coefficient and the bioturbation coefficient, to form the sand-mud-bio model.

\section{Model set-up and description of the reference situation}

\subsection{Hydrodynamical and morphological model set-up}

The sand-mud-bio model is tested for a part of the Paulinapolder intertidal flat (Fig. 1). The area modelled is about $5 \mathrm{~km}$ long and $1 \mathrm{~km}$ wide, the area of interest being located in the center (Fig. 5). For the set-up of the hydrodynamic model, bathymetric data and flow measurements are used. The tide is the main forcing factor in the model. A tide with an amplitude of $2.5 \mathrm{~m}$ and period of $12 \mathrm{~h}$ and $25 \mathrm{~min}$ is prescribed as boundary condition at the eastern model boundary. Under this spring tide condition, the whole area is flooded during a tidal cycle.

At the western boundary the flow velocity with amplitudes varying between $0.1 \mathrm{~m} \mathrm{~s}^{-1}$ (near the dike in the south) and $0.7 \mathrm{~m} \mathrm{~s}^{-1}$ (near the channel on the north) is prescribed as boundary condition. The northern and southern boundaries are both closed. This is done because it is observed that due to the local bathymetry, the tidal flat fills and empties in eastern and western direction, respectively. In Fig. 6 flow velocities during flood conditions are shown. For determining the relative phase difference between the eastern and western boundaries, it is taken into account that the time lag between the horizontal and vertical tides is about $2.5 \mathrm{~h}$ in this part of the estuary (Van den Berg et al., 1996).

The suspended sediment concentration at the open boundaries during inflow is assumed as $50 \mathrm{mg} \mathrm{l}^{-1}$, since the average suspended sediment concentration at Terneuzen over one year is $45-50 \mathrm{mg} \mathrm{l}^{-1}$ (Van Maldegem et al., 1999). The water column is schematically divided into 5 water layers, with the lowest layer being $5 \%$ of the total water depth. Bed roughness is modelled by means of a uniform Nikuradse roughness height of $0.005 \mathrm{~m}$. Flow simulations show a good agreement with observations (not shown in this paper).

The parameters from Table 1 are used to calculate vertical fluxes of suspended sand and mud using Eqs. (1)-(4). A critical bed shear stress for deposition does not exist (Winterwerp and Van Kesteren, 2004). Since, in general, bed shear stresses range from 0.10 to $0.60 \mathrm{~N} \mathrm{~m}^{-2}$ in the area modelled, the critical bed shear stress for deposition was set to $1.5 \mathrm{~N} \mathrm{~m}^{-2}$. Notice that the heavyside function in Eqs. (3) and (4) is 1, if the argument is greater than zero. This condition is satisfied with a high critical bed shear stress for deposition.

Morphological response takes place on a much longer time scale than typical hydrodynamic changes. Therefore the morphological time step is chosen such that, after one tidal cycle, the bed level change of 10 tidal cycles is simulated. The settling velocity for mud is assumed to be $5 \mathrm{~m} \mathrm{day}^{-1}\left(\sim 0.06 \mathrm{~mm} \mathrm{~s}^{-1}\right)$ at a reference temperature of $20^{\circ} \mathrm{C}$, following Van Rijn (1993).

The sand-mud model uses a range of parameters to calculate bed composition variations over time (Table 2). In this paper, a critical mud content of $20 \%$ by weight

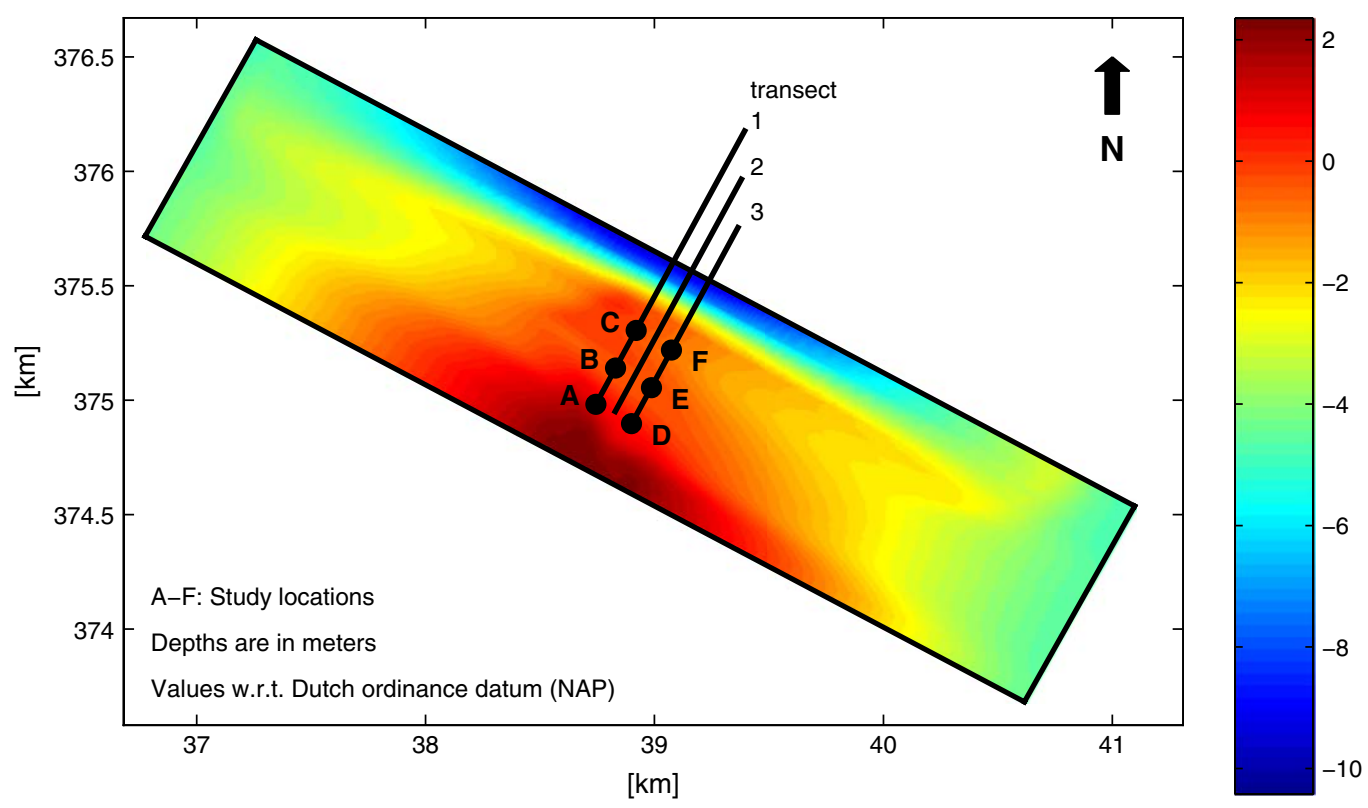

Fig. 5. Bathymetry of the modelled area. In the south, the area is bounded by a dike and in the north by a channel. Three transects are included for later reference. 


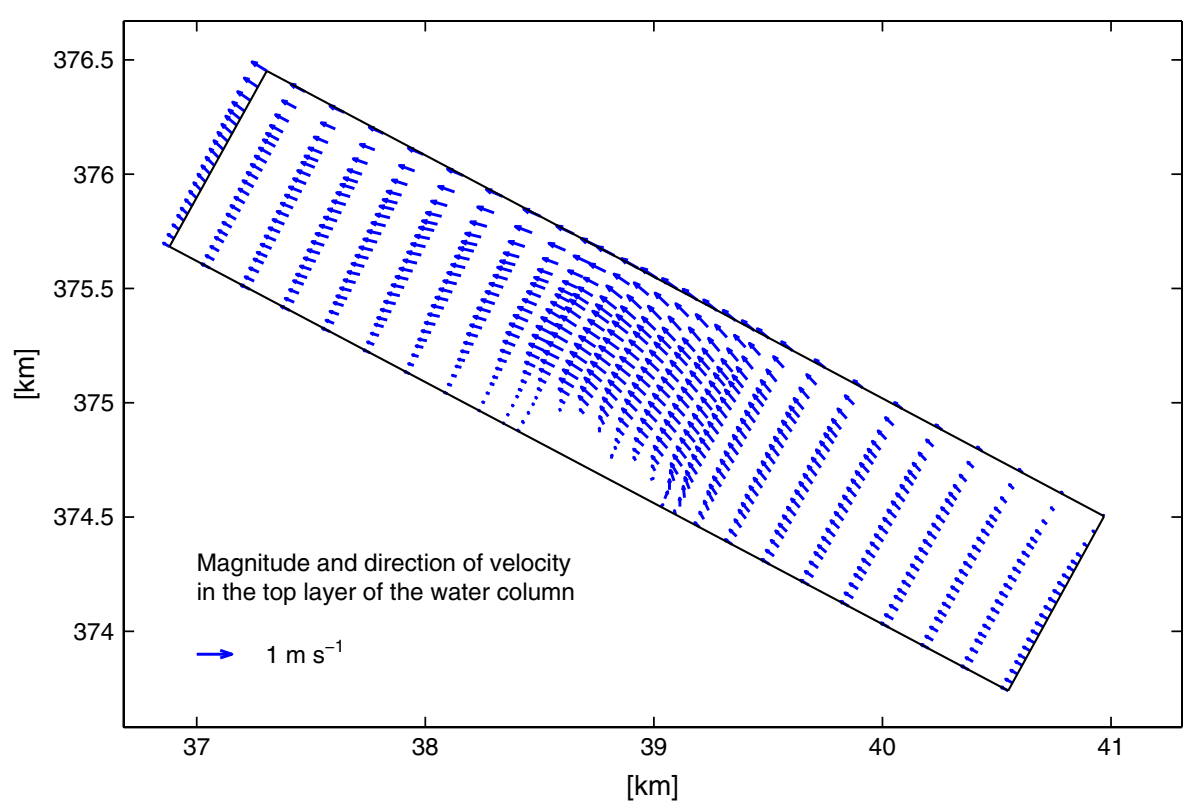

Fig. 6. Flow pattern during flood, i.e. filling of the flat.

for each layer is applied (which conforms the findings of Houwing (1999), who found a substantial decrease in erosion rates at mud contents higher than $20 \%$ mud by weight), which is slightly lower than the value used by Van Ledden and Wang (2001) (viz. 0.3). The sediment bed is schematically divided into six layers of $5 \mathrm{~cm}$ each, which gives a total simulated sediment bed thickness of $30 \mathrm{~cm}$ (Fig. 7). For model simulations including biological activity, an initial bed profile is assumed, and the biological mixing zone is set to $20 \mathrm{~cm}$ (Fig. 7), which is in agreement with published data (Boudreau, 1997). Biological mixing is assumed to be constant in the biological mixing zone.

Table 1

Morphological parameters that determine erosion (first four parameters) and sedimentation (last two parameters) of sediment. All parameters are for a situation free of biological activity

\begin{tabular}{llll}
\hline Description of variable & Symbol & Value & Units \\
\hline $\begin{array}{c}\text { Critical erosion } \\
\text { shear stress (non- } \\
\text { cohesive regime) }\end{array}$ & $\tau_{\mathrm{nc}}^{0}$ & 0.35 & $\mathrm{~N} \mathrm{~m}^{-2}$ \\
$\begin{array}{c}\text { Erosion coefficient } \\
\quad \text { non-cohesive regime) }\end{array}$ & $M_{\mathrm{nc}}^{0}$ & $1 \times 10^{-5}$ & $\mathrm{~m} \mathrm{~s}^{-1}$ \\
$\begin{array}{c}\text { Critical erosion } \\
\text { shear stress } \\
\quad \text { cohesive regime) }\end{array}$ & $\tau_{\mathrm{c}}^{0}$ & 0.50 & $\mathrm{~N} \mathrm{~m}^{-2}$ \\
$\begin{array}{c}\text { Erosion coefficient } \\
\quad \text { cohesive regime) }\end{array}$ & $M_{\mathrm{c}}^{0}$ & $1 \times 10^{-8}$ & $\mathrm{~m} \mathrm{~s}^{-1}$ \\
$\begin{array}{c}\text { Critical shear } \\
\text { stress for deposition }\end{array}$ & $\tau_{\mathrm{d}}$ & 1.5 & $\mathrm{~N} \mathrm{~m}^{-2}$ \\
$\begin{array}{c}\text { Settling velocity } \\
\text { for mud at } 20{ }^{\circ} \mathrm{C}\end{array}$ & $w_{\mathrm{m}}$ & $5.8 \times 10^{-5}$ & $\mathrm{~m} \mathrm{~s}^{-1}$ \\
\hline
\end{tabular}

\subsection{Reference situation}

Using the parameters from Tables 1 and 2, the sandmud-bio model is run for half a year without biological activity included to create a reference situation. Fig. 8 shows the pattern of net erosion and sedimentation over half a year in the reference situation. Figs. 9 and 10 show the resulting mud content over time and after half a year respectively. At high shore locations close to the dike in the south (A and D in Fig. 5), where energy, tidal flow velocity and resulting bed shear stresses are relatively low, the mud content increases over time (net deposition). At all other locations (mid shore and low shore), mud contents decrease over time.

Fig. 11 shows how the bed level changes after half a year for the reference situation. On a large part of the

Table 2

Bed composition parameter settings for the reference situation. All parameters are for a situation free of biological activity

\begin{tabular}{llll}
\hline Description of variable & Symbol & Value & Units \\
\hline $\begin{array}{l}\text { Bed porosity } \\
\quad \text { (both sand and mud) }\end{array}$ & $\varepsilon_{\mathrm{p}}$ & 0.4 & - \\
$\begin{array}{l}\text { Sediment density } \\
\quad \text { (both sand and mud) }\end{array}$ & $\rho_{\mathrm{s}}, \rho_{\mathrm{m}}$ & 1650 & $\mathrm{~kg} \mathrm{~m}^{-3}$ \\
$\begin{array}{l}\text { Median grain } \\
\text { size for sand }\end{array}$ & $D_{\mathrm{s}}$ & 150 & $\mu \mathrm{m}$ \\
$\begin{array}{l}\text { Median grain } \\
\text { size for mud }\end{array}$ & $D_{\mathrm{m}}$ & 20 & $\mu \mathrm{m}$ \\
$\begin{array}{l}\text { Water density } \\
\text { Critical mud content }\end{array}$ & $\rho_{\mathrm{w}}$ & 1000 & $\mathrm{~kg} \mathrm{~m}^{-3}$ \\
$\begin{array}{l}\text { Bioturbation coefficient } \\
\text { Biological mixing length }\end{array}$ & $\theta_{\mathrm{b}}$ & 0.20 & - \\
\hline
\end{tabular}




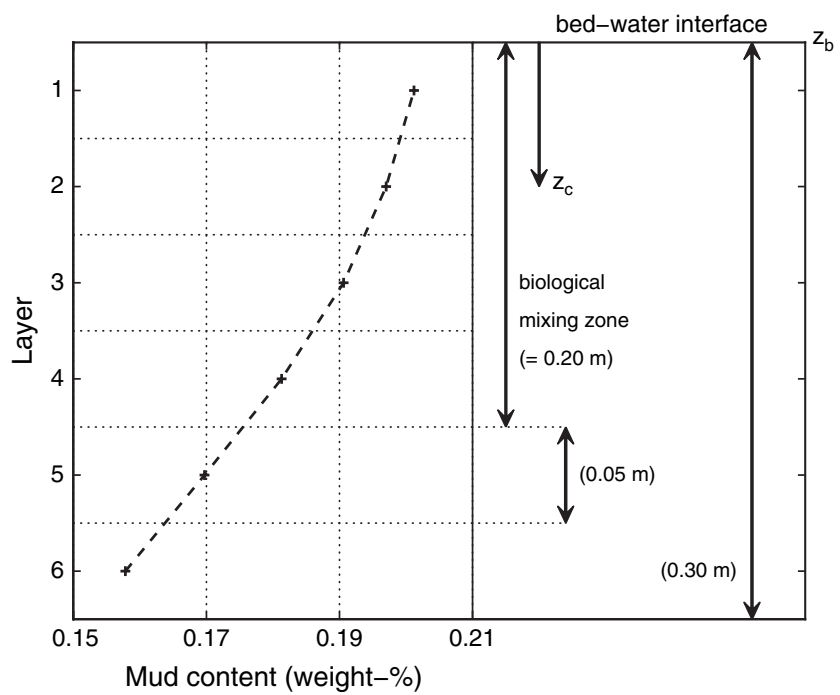

Fig. 7. Left part: mud content as weight- $\%$ in each bed layer (vertical bed composition) at location A in the reference situation. Right part: variable definitions in the bed. The bed-water interface is at $z_{\mathrm{b}}=0$, which coincides with $z_{\mathrm{c}}=0 . z_{\mathrm{c}}$ is the coordinate pointing from the bed-water interface downwards in the bed. The thickness of a layer, and the depth of the bioturbation zone are also shown.

transect, erosion can be observed. Large bed level variations near the channel are a result of a coarser grid outside the area of interest.

\section{Results of three test cases}

To study the biological influences on bed composition and bed level, three different test cases are investigated. The results from these test cases are compared with the reference situation (Section 4). Test case 1 studies the influence of destabilizing organisms and test case 2 the effect of stabilizing organisms. The effect of spatial variations in biological activity is studied in test case 3. The simulated time span covers half a year, assuming constant biological activity over time.

\subsection{Test case 1 - maximum destabilizing biological influence}

High densities of destabilizing organisms are present in the Paulinapolder. We assume the density of destabilizing organisms constant at 3000 indiv. $\mathrm{m}^{-2}$. In comparison, De Brouwer et al. (2000) found Macoma densities up to 1192 indiv. $\mathrm{m}^{-2}$ in the Biezelingse Ham in the Western Scheldt. De Deckere et al. (2001) found values for Macoma of up to about 10,000 indiv. $\mathrm{m}^{-2}$ in the Humber estuary. As a result, the sediment is destabilized. The critical bed shear stress is lower $\left(\tau_{\mathrm{cr}}=0.42 \tau_{\mathrm{cr}}^{0}\right)$, and the erosion and bioturbation coefficients are higher $\left(M=12.81 M^{0}\right)$ (Eqs. (6)-(10), and Fig. 2).

Over a time span of half a year, mud contents decrease compared to the reference situation free of biological activity (Fig. 10). Fig. 11 shows similar effects on the bed level. Close to the salt marsh, the bed level remains constant, but farther from the salt marsh more erosion occurs compared to the reference situation. The erosion is especially significant at mid and low shore locations.

The differences in mud content between the reference situation and the destabilized situation is large at high shore locations close to the salt marsh, and small at mid

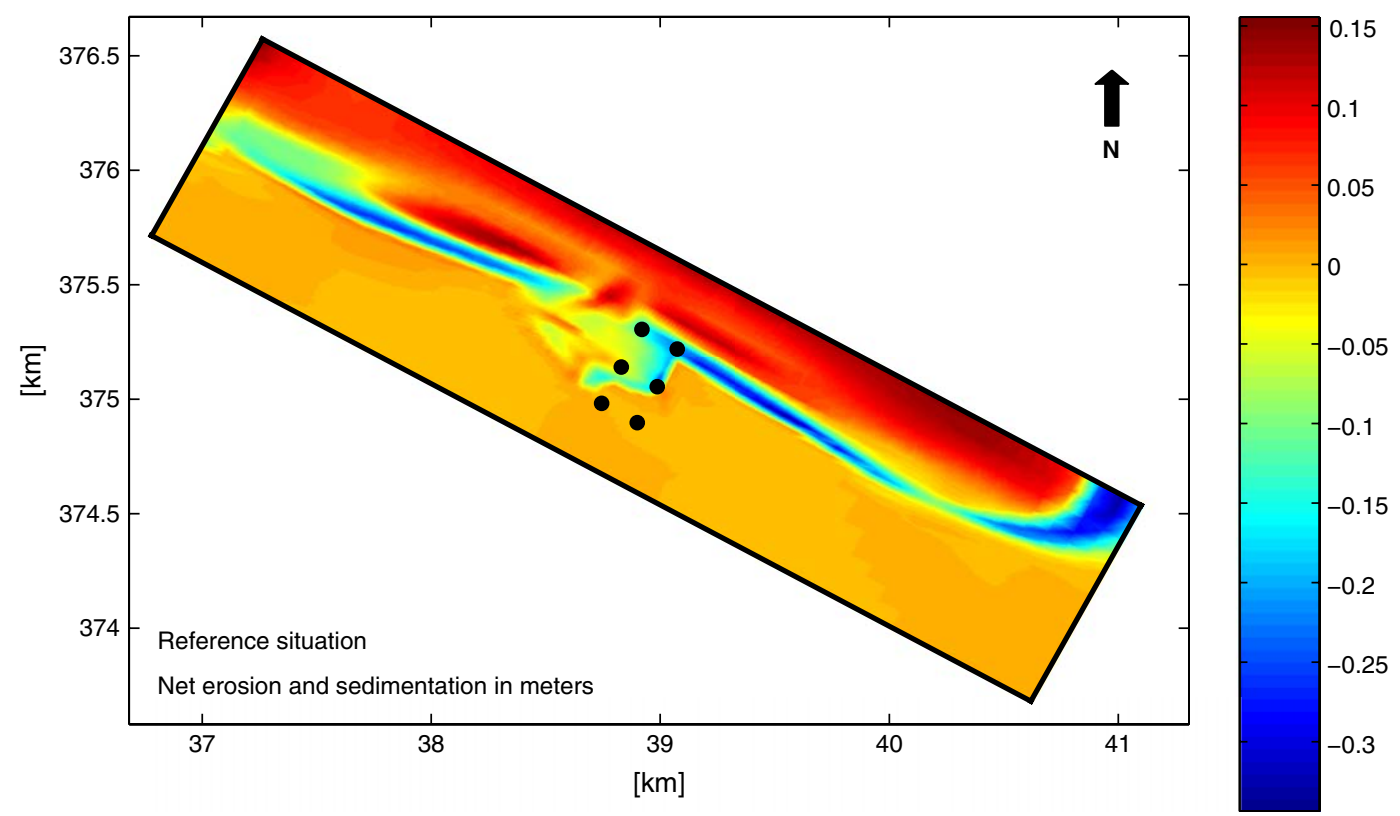

Fig. 8. General pattern of erosion and sedimentation in the reference situation; negative values imply erosion. 


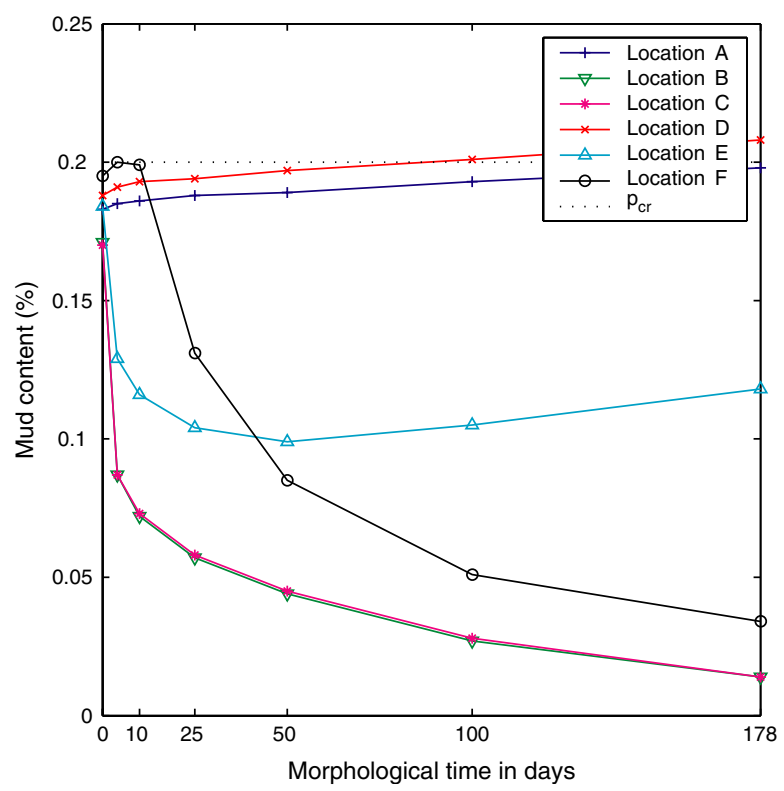

Fig. 9. Depth-averaged mud content, in the top $30 \mathrm{~cm}$ of the sediment bed, over time in a situation free of biological activity (the reference situation).

and low shore locations (Fig. 10). The critical bed shear stress is essential to explain this spatial difference. At locations $\mathrm{A}$ and $\mathrm{D}$, for example, the bed shear stress is below the critical bed shear stress in the reference situation. If the bed is destabilized, the critical bed shear stress becomes lower, and erosion of mud occurs.

Besides the critical bed shear stress becoming lower, a second effect of biodestabilization is an increase in erosion coefficient. This change in erosion coefficient affects rate at which equilibrium is approached (but not the equilibrium state itself). Therefore, the amount of erosion is equal as in the reference situation on a large part of the transect.

A third effect of biodestabilization is that more sediment is mixed between individual sediment layers (e.g. the bioturbation coefficient is larger), according to

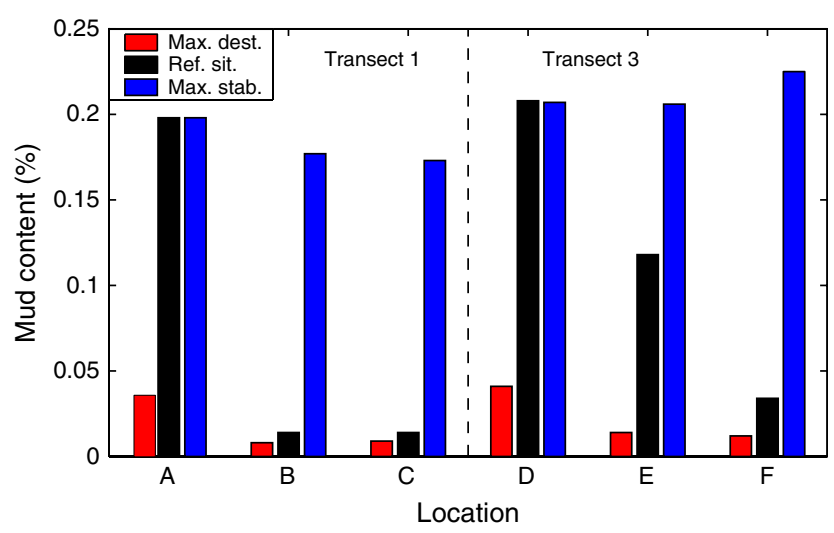

Fig. 10. Depth-averaged mud content in the top $30 \mathrm{~cm}$ of the sediment bed after half a year.
Eq. (5). Bioturbation acts to eliminate gradients in mud content by moving material down the gradient (Boudreau, 1997). As a result of the initially non-uniform vertical bed composition (Fig. 7), the mud content in the top layer of the sediment bed becomes lower, and in the lower layers it increases.

Fig. 12a shows the development of the mud content at location D over time, when the sediment is destabilized. Starting values of mud contents are based on the results of a biology-free spin-up run establishing an initial spatial distribution pattern of mud in agreement with local physical forcings. After day 25, the mud content in the top layer of the bed decreases below the critical mud content, and the bed becomes non-cohesive. This may be due to the fact that the mud in the bed is redistributed over individual layers to give a constant vertical profile of mud content, or due to the above described effect of an increased bioturbation coefficient. It results in a lower critical erosion shear stress (Table 1) that causes increased erosion and rapidly decreasing mud contents. If the trend in Fig. 12a is maintained, all the mud is likely to disappear completely over time.

\subsection{Test case $2-$ maximum stabilizing biological influence}

High contents of stabilizing organisms are present in the Paulinapolder. In general, around May and June, highest contents of Chlorophyll $a$ are measured. In this test case, we assume that the diatom content is constant (over time) at $50 \mu \mathrm{g} \mathrm{g}^{-1}$ sediment. In comparison, De Brouwer et al. (2000) measured contents up to $35 \mu \mathrm{g} \mathrm{g}^{-1}$ for the Western Scheldt, Austen et al. (1999) measured contents up to $219.1 \mu \mathrm{g} \mathrm{g}^{-1}$ for Lister Dyb tidal area in the Danish Wadden Sea, and Staats et al. (2001) measured values of up to $219.1 \mu \mathrm{g} \mathrm{g}^{-1}$ in the Ems Dollard estuary. As a result, sediment stability is increased. The critical bed shear stress is higher $\left(\tau_{\mathrm{cr}}=4.5 \tau_{\mathrm{cr}}^{0}\right)$, and the erosion coefficient is lower $\left(M=0.08 M^{0}\right)$ (Eqs. (6)-(9), and Fig. 2). The bioturbation coefficient remains the same as in the reference situation since it is assumed that bioturbation is independent on the diatom content.

Fig. 10 shows that at high shore locations, the mud content is the same as in the reference situation. However, at offshore locations the mud content is higher after half a year, compared to the reference situation. On a large part of transect 2, the changes in parameters do not change the behaviour of the system (Fig. 11). However, at mid and low shore locations some additional sedimentation is observed.

Fig. 11 shows accretion of sediment near the channel bank in all cases (also in the maximally destabilized case). This has to do with the reference situation not being fully in equilibrium. In the reference situation, sediment is deposited at the channel bank (Fig. 11). Since flow energy is so high near the channel, 


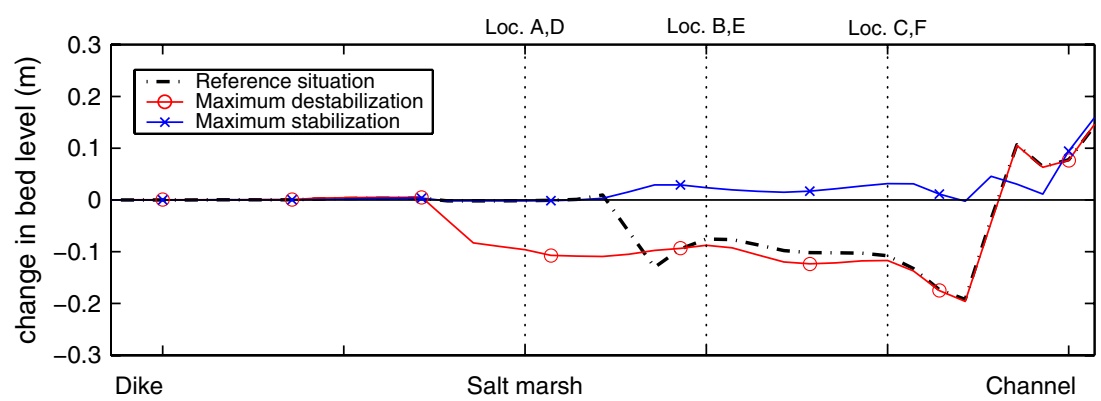

Fig. 11. Biological influence on the bed level at transect 2 for the situation without biological activity (reference situation) or maximal biological activity. Values are relative to the initial bed level at the start of the simulation; negative values imply erosion.

destabilization has no additional effect on sediment transport, since the critical bed shear stress is already exceeded in the reference situation. Therefore, the morphological behaviour at the channel bank is the same for the reference situation and in the case of maximal destabilization of the bed. In the maximally stabilized case, less deposition occurs, because less sediment is available.

The observed sedimentation on large part of the flat is a result of stabilizing organisms which cause a high critical bed shear stress. The bed shear stress is below the critical bed shear stress over the total time span of the simulation and no (bed load) sediment transport of either sand or mud occurs on the flat. As a consequence, mud contents are influenced only by deposition of sediment and sediment mixing between individual bed layers. Fig. 12b shows that sedimentation does indeed occur at (for instance) location F.

On the Paulinapolder intertidal flat, a stabilizing biological influence results in a non-erosional system. Stabilizing organisms can - but do not necessarily cause accretion and increasing mud contents.

\subsection{Test case 3 - spatially variable biological activity}

Biological organisms are usually not spread uniformly, but occur in patches (Fig. 13). As a result, areas with many destabilizing and stabilizing organisms exist. In this case, it is tested whether this results in bed level and bed composition variations between patches. To simulate the observed horizontal patchiness we apply a fine horizontal grid of $20 \times 20 \mathrm{~m}$ to the intertidal flat. Biological activity is constant over horizontal patches of $60 \times 60 \mathrm{~m}$.

In Fig. 14, the biological influence is shown when biological activity varies on a 'chessboard' pattern (e.g. alternating destabilized and stabilized patches) over a time span of half a year. The same Macoma density and diatom content are used as in test cases 1 and 2, respectively. On destabilized patches (e.g. locations with erosion of about $15 \mathrm{~cm}$ in Fig. 14), erosion is slightly higher compared to the situation with maximum de- stabilization over the total area. On stabilized patches (locations I-IV in Fig. 14), the erosion and sedimentation pattern is the same as in the maximally stabilized situation (locations I and II), or erosion occurs compared to the maximally stabilized situation (locations III and IV).

These slight differences result from bed level variations of $10-15 \mathrm{~cm}$ between destabilized and stabilized patches. The flow velocities vary due to these water depth variations between the patches. The morphological responses are local, and sediment is redistributed between stabilized and destabilized patches. A small part (about $4.5 \%$ ) of the eroded sediment is transported across the open boundaries.

\section{Discussion}

This paper describes the modelling of biological influences on morphological changes and vertical bed composition. However, in general, the biogeomorphological interaction is more complex. Bed level changes affect species abundance, and interactions between organisms occur (e.g., diatoms form the main diet of Macoma balthica). It will be a challenge to implement the complete biogeomorphological interaction into geomorphological models. In this paper, it is shown that the biological influences on sediment strength are significant within the complex biogeomorphological interaction.

In the parameterization of biological influences, Macoma density is used. In ecology, Macoma biomass is a generally accepted indicator. However, there is no indication yet that it is the better variable of the two, since Macoma density correlates better with critical bed shear stress and erosion coefficient. A disadvantage in using Macoma density is the fact that it is uncertain whether one large organism (in terms of biomass) has the same effect on sediment strength as two small organisms with the same total biomass as the larger organism.

To deduce the biological influences on the critical bed shear stress and the erosion coefficient relatively small data sets are used, leading to uncertainty in the regression. As a result, the ranges of extrapolation are quite large. 

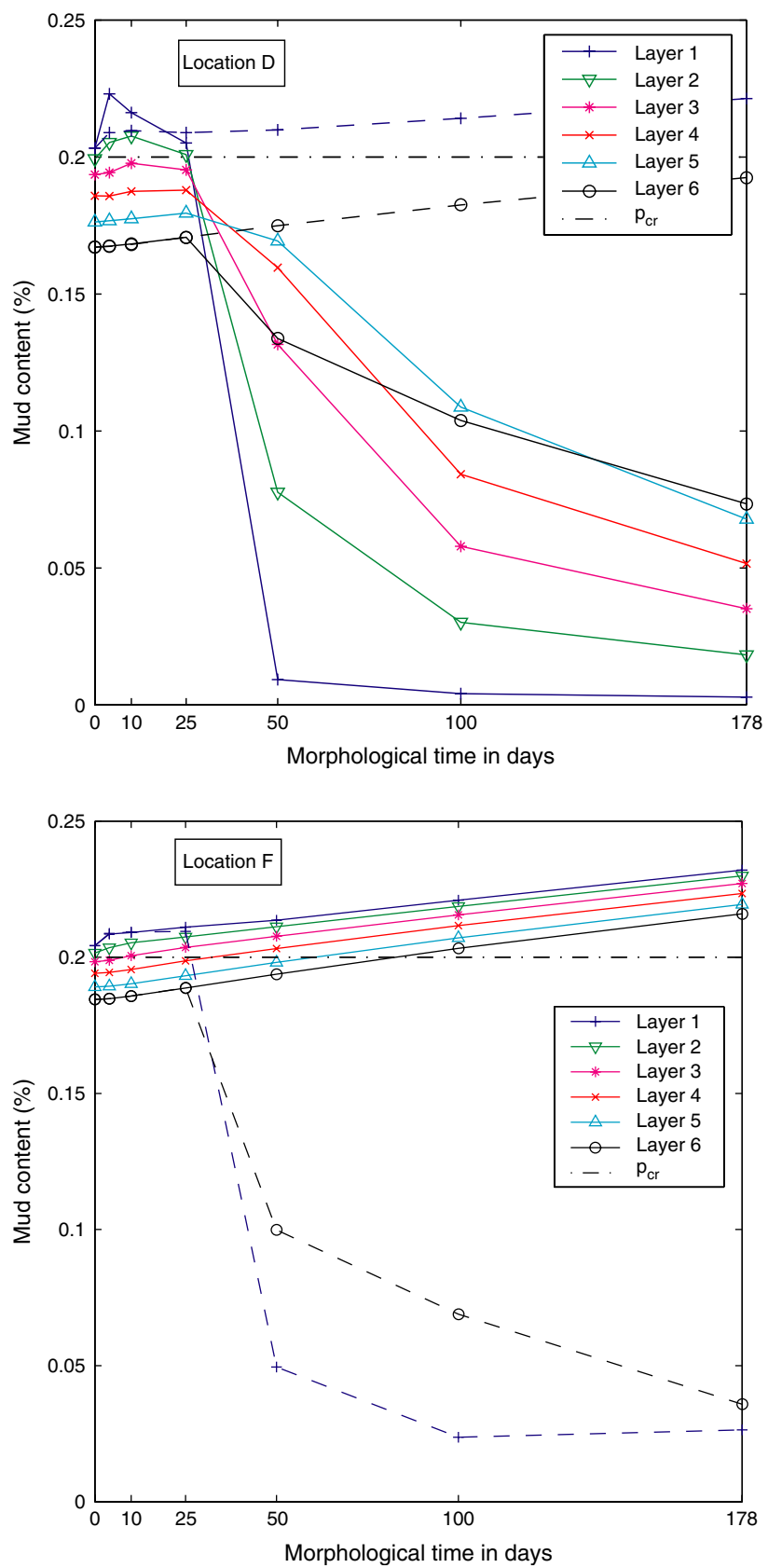

Fig. 12. Mud content, as percentage of the total amount of sediment, over time when the sediment bed is maximally destabilized (a) and maximally stabilized (b). The dashed lines give the mud content over time in the reference situation for layer 1 (top layer) and layer 6.

Flow simulations show good agreement with observations. To simulate the expected morphological response of the flat, a sensitivity analysis is performed. Parameters are selected such that results are in agreement with expectations based on physical knowledge. The model results depend on initial conditions and on assumed critical values. Therefore the model results are only valid for this particular study case (the Paulinapolder).

The transition between the cohesive and the noncohesive regime is important. This transition depends on the assumed critical mud content. When a transition between the cohesive and non-cohesive regime occurs, the parameters that determine the erosional processes (the critical bed shear stress and erosion coefficient) also change. This causes erosion and quickly decreasing mud contents. In reality, this transition between regimes will be smoother. In the sand-mud model no bed load transport of sand is possible in the cohesive regime. When a transition from the cohesive to the non-cohesive regime occurs, suddenly bed load sand transport becomes possible what strongly affects the system. High energy events could also lead to sudden disruption of the cohesion, making bed load transport possible.

Probably, the accretion resulting from mud deposition is underestimated in the model. This can be understood as follows. In the model, porosity and density of both sand and mud are equal. However, in reality, the porosity of mud is greater (about 0.8 instead of 0.4 ) and the wet density is smaller (about 1400 instead of $\left.2050 \mathrm{~kg} / \mathrm{m}^{3}\right)$. In the sand-mud-bio model, consolidation of the sediment is not accounted for, however, Quaresma et al. (2004) have shown that this process is very important for stabilization.

According to Boudreau (1997) the bioturbation coefficient is depth dependent, while we assume it as constant (Fig. 7). Biological activity is assumed to be constant during the time span of a simulation. However, in reality, temporal variations are likely to occur. Diatom contents increase during spring time, for instance. In this paper, these variations are not considered. If biological activity varies spatially it is likely that organisms will move between patches. It is likely that in times with a lot of destabilizing organisms on the flat, the system will get sandier. On the other hand, when a lot of stabilizing organisms are present, mud contents are likely to increase.

\section{Conclusions}

To analyze the biological influences on bed composition and morphological change, a parameterization of the biological influences on three sediment strength parameters is proposed in this paper. These parameters are the critical bed shear stress, the erosion coefficient and the bioturbation coefficient. With the new sandmud-bio model (based on the numerical model Delft3D, including sand-mud morphodynamics), we show that biological activity has a significant influence on morphological change and bed composition for the Paulinapolder intertidal flat.

Destabilizing organisms always cause a significant decrease of mud content in the bed and an increase of erosion. These organisms lower the critical bed shear stress, increase the erosion coefficient and increase the bioturbation coefficient. Bioturbation results in mixing 


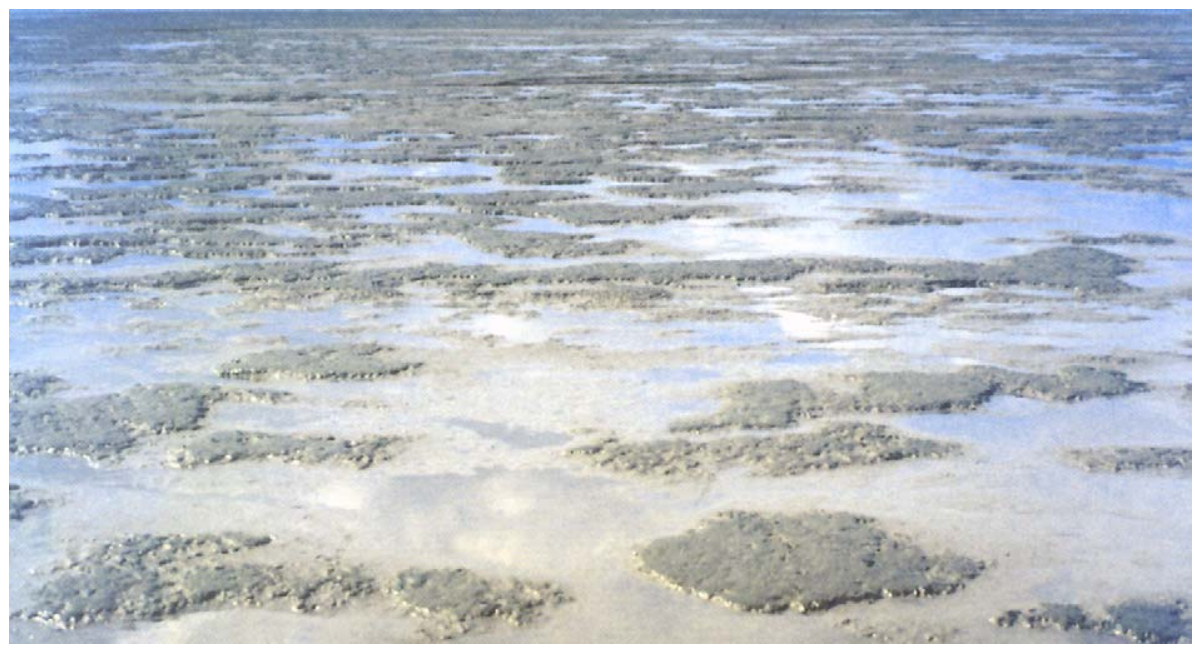

Fig. 13. Patches of biological activity on a tidal flat in the Dollard estuary, June 1996. (Image courtesy: E.M.G.T. De Deckere, present address: University of Antwerp, Department of Biology, Wilrijk, Belgium.)

of sediment between bed layers. Consequently more mud is removed and the mud content in the top layer of the sediment bed decreases. At some locations in the Paulinapolder, this means that the bed becomes noncohesive.

On the other hand, stabilizing organisms can - but do not necessarily - cause an increase in mud content and additional sedimentation. The increased critical bed shear stress and lower erosion coefficient cause erosion to decrease to zero. As suspended mud is still deposited, mud contents increase slightly over time. It seems that the steep slope of the shoal near the channel is more stable as a result of the stabilizing effect of algae.

If biological activity varies spatially, then the general effects of destabilization and stabilization are similar. Slight differences are caused by variations in flow velocities in between patches. Bed level variations in between patches are $10-15 \mathrm{~cm}$, resulting in different water depths.

The approach of including biological activity in a parameterized way is an important step towards including biological activity in numerical morphodynamic models. The parameterization proposed in this paper offers good opportunities to study the biogeomorphological interaction further.

\section{List of symbols}

$p_{\text {cr }} \quad$ critical mud content $[-]$

$p_{\mathrm{m}} \quad$ mud content in the sediment exchange layer [-]

$F_{\text {s }} \quad$ net vertical flux of suspended sand near the bed surface $\left[\mathrm{m} \mathrm{s}^{-1}\right]$

$F_{\mathrm{m}} \quad$ net vertical flux of suspended mud near the bed surface $\left[\mathrm{m} \mathrm{s}^{-1}\right]$

$w_{\mathrm{s}} \quad$ settling velocity for sand at $20{ }^{\circ} \mathrm{C}\left[\mathrm{m} \mathrm{s}^{-1}\right]$

$w_{\mathrm{m}} \quad$ settling velocity for mud at $20^{\circ} \mathrm{C}\left[\mathrm{m} \mathrm{s}^{-1}\right]$

$c_{\mathrm{a}} \quad$ reference sand volume concentration [-]

$c_{\mathrm{s}} \quad$ sand volume concentration near the bed surface [-]

$c_{\mathrm{m}} \quad$ mud volume concentration near the bed surface $[-]$

$M_{\mathrm{c}}$ erosion coefficient for the cohesive regime $\left[\mathrm{m} \mathrm{s}^{-1}\right]$

$M_{\mathrm{nc}} \quad$ erosion coefficient for the non-cohesive regime $\left[\mathrm{m} \mathrm{s}^{-1}\right]$

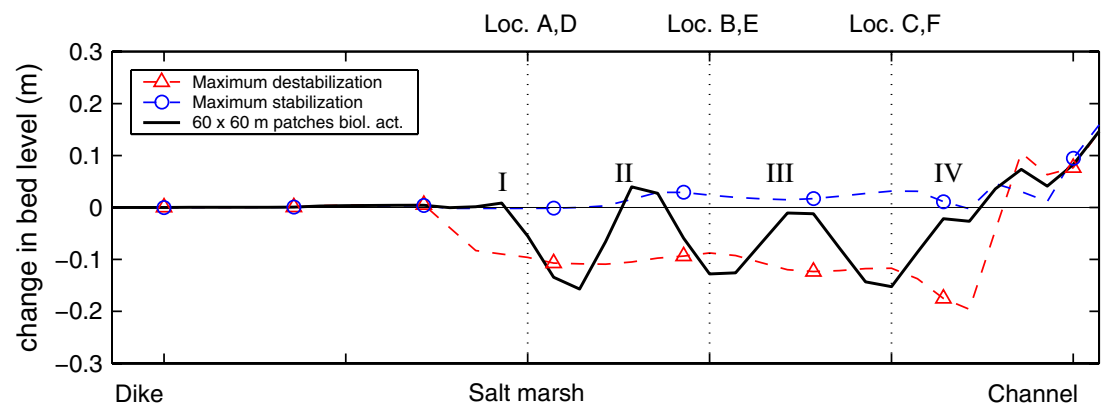

Fig. 14. Biological influence on the bed level at transect 2 if biological activity varies spatially with a chessboard pattern. Values are relative to the initial bed level at the start of the simulation; negative values imply erosion. 


\begin{tabular}{|c|c|}
\hline$\tau_{\mathrm{b}}$ & bed shear stress $\left[\mathrm{N} \mathrm{m}^{-2}\right]$ \\
\hline$\tau_{\mathrm{c}}$ & $\begin{array}{l}\text { critical erosion shear stress for the cohesive } \\
\text { regime }\left[\mathrm{N} \mathrm{m}^{-2}\right]\end{array}$ \\
\hline$\tau_{\mathrm{nc}}$ & $\begin{array}{l}\text { critical erosion shear stress for the non-cohesive } \\
\text { regime }\left[\mathrm{N} \mathrm{m}^{-2}\right]\end{array}$ \\
\hline$\tau_{\mathrm{d}}$ & critical shear stress for mud deposition $\left[\mathrm{N} \mathrm{m}^{-2}\right]$ \\
\hline$H$ & heavyside function \\
\hline$z_{\mathrm{b}}$ & bed surface level $[\mathrm{m}]$ \\
\hline$z_{\mathrm{c}}$ & distance below the bed surface $z_{\mathrm{b}}[\mathrm{m}]$ \\
\hline$\theta_{\text {mix }}$ & mixing coefficient $\left[\mathrm{m}^{2} \mathrm{~s}^{-1}\right]$ \\
\hline$\theta_{\mathrm{p}}$ & $\begin{array}{l}\text { physical mixing component due to small-scale } \\
\text { bed level disturbances }\left[\mathrm{m}^{2} \mathrm{~s}^{-1}\right]\end{array}$ \\
\hline$\theta_{\mathrm{b}}$ & local biological mixing component $\left[\mathrm{m}^{2} \mathrm{~s}^{-1}\right]$ \\
\hline$\theta_{\mathrm{d}}$ & $\begin{array}{l}\text { bioturbation coefficient including biological } \\
\text { activity }\left[\mathrm{m}^{2} \mathrm{~s}^{-1}\right]\end{array}$ \\
\hline$\tau_{\mathrm{cr}}$ & critical bed shear stress $\left[\mathrm{N} \mathrm{m}^{-2}\right]$ \\
\hline$M$ & erosion coefficient $\left[\mathrm{m} \mathrm{s}^{-1}\right]$ \\
\hline$f_{\mathrm{s}}$ & $\begin{array}{l}\text { abilizing influences on the critical bed shear } \\
\text { ress [-] }\end{array}$ \\
\hline$f_{\mathrm{d}}$ & $\begin{array}{l}\text { destabilizing influences on the critical bed shear } \\
\text { stress [-] }\end{array}$ \\
\hline$g_{\mathrm{s}}$ & $\begin{array}{l}\text { stabilizing influences on the erosion coefficient } \\
{[-]}\end{array}$ \\
\hline$g_{\mathrm{d}}$ & $\begin{array}{l}\text { destabilizing influences on the erosion coeffi- } \\
\text { cient }[-]\end{array}$ \\
\hline$C$ & $\begin{array}{l}\text { Chlorophyll } a \text { content on the sediment }\left[\mu \mathrm{g} \mathrm{g}^{-1}\right. \\
\text { sediment }]\end{array}$ \\
\hline$B$ & Macoma density $[-]$ \\
\hline & maximum erosion coefficient $\left[\mathrm{m} \mathrm{s}^{-1}\right]$ \\
\hline$I$ & initial erosion rate $\left[\mathrm{m} \mathrm{s}^{-1}\right]$ \\
\hline$b_{1}$ & regression coefficient $[-]$ \\
\hline$b_{2}$ & regression coefficient $\left[\mathrm{m} \mathrm{s}^{-1}\right]$ \\
\hline
\end{tabular}

\section{Acknowledgements}

We thank Mathijs van Ledden and WL | Delft Hydraulics for providing the sand-mud model. This research originated from a cooperation of several companies and institutes in the Delft Cluster program; Theme 3: Coast and River. This project is co-financed by the Department of Economic Affairs of the Netherlands government. Financial contributions are made available from 'Doelfinanciering Westerschelde' (WL Delft Hydraulics, Z2832) and EUMARSAND (HPRNCT-2002-00222).

\section{References}

Armanini, A., 1995. Non-uniform sediment transport: dynamics of the active layer. Journal of Hydraulic Research 33, 611-622.

Austen, I., Andersen, T.J., Edelvang, K., 1999. The influence of benthic diatoms and invertebrates on the erodibiliy of an intertidal mudflat, the Danish Wadden Sea. Estuarine, Coastal and Shelf Science 49, 99-111.
Boudreau, B.P., 1997. Diagenetic Models and Their Implementation. Modelling Transport and Reactions in Aquatic Sediments. Springer-Verlag, Berlin (Chapter 3), pp. 41-47.

Decho, A.W., 2000. Microbial biofilms in intertidal systems: an overview. Continental Shelf Research 20, 1257-1273.

De Deckere, E.M.G.T., Tolhurst, T.J., De Brouwer, J.F.C., 2001. Destabilization of cohesive intertidal sediments by infauna. Estuarine, Coastal and Shelf Science 53, 665-669.

De Brouwer, J.F.C., Bjelic, S., De Deckere, E.M.G.T., Stal, L.J., 2000. Interplay between biology and sedimentology in a mudflat (Biezelingse Ham, Westerschelde, The Netherlands). Continental Shelf Research 20, 1159-1177.

Flemming, B.W., Delafontaine, M.T., 2000. Mass physical properties of muddy intertidal sediments: some applications, misapplications and non-applications. Continental Shelf Research 20, 1179-1197.

Houwing, E.J., 1999. Determination of the critical erosion threshold of cohesive sediments on intertidal mudflats along the Dutch Wadden Sea coast. Estuarine, Coastal and Shelf Science 49, 545-555.

Jumars, P.A., Nowell, A.R.M., 1984. Effects of benthos on sediment transport: difficulties with functional grouping. Continental Shelf Research 3, 115-130.

Knaapen, M.A.F., Holzhauer, H., Hulscher, S.J.M.H., Baptist, M.J., De Vries, M.B., Van Ledden, M., 2003. On the modelling of biological effects on morphology in estuaries and seas. In: SánchezArcilla, A., Bateman, A. (Eds.), Proceedings of the Third IAHR Symposium on River, Coastal and Estuarine Morphodynamics Conference. IAHR, Barcelona, Spain, pp. 773-783.

Lee, H., Swartz, R.C., 1980. Biological processes affecting the distribution of pollutants in marine sediments. Part ii. Biodeposition and bioturbation. In: Baker, R.A. (Ed.), Analysis, Chemistry, Biology. Contaminants and Sediments, vol. 2. Ann Arbor Science, Ann Arbor, MI, pp. 555-594.

Paterson, D.M., Tolhurst, T.J., Kelly, J.A., Honeywill, C., De Deckere, E.M.G.T., Huet, V., Shayler, S.A., Black, K.S., De Brouwer, J., Davidson, I., 2000. Variations in sediment properties, Skeffling mudflat, Humber Estuary, UK. Continental Shelf Research 20, 1373-1396.

Quaresma, V.S., Amos, C.L., Flindt, M., 2004. The influences of biological activity and consolidation time on laboratory cohesive beds. Journal of Sedimentary Research 74, 184-190.

Reise, K., 2002. Sediment mediated species interactions in coastal waters. Journal of Sea Research 48, 127-141.

Riethmüller, R., Heineke, M., Kühl, H., Keuker-Rüdiger, R., 2000. Chlorophyll $a$ concentration as an index of sediment surface stabilisation by microphytobenthos? Continental Shelf Research 20, 1351-1372.

Staats, N., De Deckere, E.M.G.T., De Winder, B., Stal, L.J., 2001. Spatial patterns of benhic diatoms, carbohydrates and mud on a tidal flat in the Ems-Dollard estuary. Hydrobiologia 448, 107-115.

Sutherland, T.F., Amos, C.L., Grant, J., 1998. The effect of buoyant biofilms on the erodability of sublittoral sediment of a temperate microtidal estuary. Limnology and Oceanography 43, 225-235.

Temmerman, S., Govers, G., Wartel, S., Meire, P., 2003. Spatial and temporal factors controlling short-term sedimentation in a salt and freshwater tidal marsh, Scheldt estuary, Belgium, SW Netherlands. Earth Surface Processes and Landforms 28 (7), 739-755.

Van den Berg, J.H., Jeuken, C.J.L., Van der Spek, A.J.F., 1996. Hydraulic processes affecting the morphology and evolution of Westerschelde estuary. In: Nordstorm, K.F., Roman, C.T. (Eds.), Estuarine Shores: Evolution, Environments and Human Alterations. John Wiley, London, pp. 157-184.

Van Ledden, M., 2002. A process-based sand-mud model. In: Winterwerp, J.C., Kranenburg, C. (Eds.), Proceedings of Marine Science. Elsevier, Amsterdam, pp. 577-594.

Van Ledden, M., 2003. Sand-mud segregation in estuaries and tidal basins. Communications on Hydraulic and Geotechnical 
Engineering, Report no. 03-2. Delft University of Technology, Delft, The Netherlands.

Van Ledden, M., Wang, Z.B., 2001. Sand-mud morphodynamics in a former estuary. In: Proceedings of the Second IAHR symposium on River, Coastal and Estuarine Morphodynamics Conference. Hokkaida Univ. press, Obihiro, Japan, pp. 505-514.

Van Ledden, M., Van Kesteren, W.G.H., Winterwerp, J.C., 2004a. A conceptual framework for the erosion behaviour of sand-mud mixtures. Continental Shelf Research 24, 1-11.

Van Ledden, M., Wang, Z.B., Winterwerp, H., De Vriend, H., 2004 b. Sand-mud morphodynamics in a short tidal basin. Ocean Dynamics 54, 385-391.

Van Maldegem, D., De Winder, B., Arends, A., 1999. Mud in the Western Scheldt: a description of the turbidity en mud distribution in the Western Scheldt for the period December 1998 until July 1999. Report RIKZ-99.026. Rijkswaterstaat, Rijksinstituut voor Kust en Zee (RWS, RIKZ) (in Dutch).

Van Rijn, L.C., 1993. Principles of Sediment Transport in Rivers, Estuaries and Coastal Seas. Aqua Publisher, Amsterdam.

Widdows, J., Brinsley, M., Elliott, M., 1998. Use of in situ flume to quantify particle flux (biodeposition rate and sediment erosion) for an intertidal mudflat in relation to changes in current velocity and benthic macrofauna. In: Black, K.S., Paterson, D.M., Cramp, A. (Eds.), Sedimentary Processes in the Intertidal Zone, vol. 139. Geological Society London, pp. 85-97 (Special Publications).

Widdows, J., Brinsley, M.D., Salkeld, P.N., Lucas, C.H., 2000a. Influence of biota on spatial and temporal variation in sediment erodability and material flux on a tidal flat (Westerschelde, The Netherlands). Marine Ecology Progress Series 194, 23-37.

Widdows, J., Brown, S., Brinsley, M.D., Salkeld, P.N., Elliott, M., 2000b. Temporal changes in intertidal sediment erodability: influence of biological and climatic factors. Continental Shelf Research 20, 1275-1289.

Widdows, J., Brinsley, M.D., 2002. Impact of biotic and abiotic processes on sediment dynamics and the consequences to the structure and functioning of the intertidal zone. Journal of Sea Research 48, 143-156.

Winterwerp, J.C., Van Kesteren, W.G.M., 2004. Introduction to the physics of cohesive sediment dynamics in the marine environment. Developments in Sedimentology, vol. 56. Elsevier, Amsterdam.

Wood, R., Widdows, J., 2002. A model of sediment transport over an intertidal transect, comparing the influences of biological and physical factors. Limnology and Oceanography 47, $848-855$. 